\title{
Exile and Nostalgia in Albanian Lyric Poetry since 1750
}

\section{0’den Bugüne Arnavut Lirik Şïrinde Sürgün ve Nostalji}

\begin{abstract}
Adam GOLDWYN ${ }^{*}$
Abstract: Albanian literature in general - and poetry in particular - has received little scholarly attention outside the Balkans, and yet this literature has much to offer reader and critic alike. Robert Elsie, one of the few Albanologists working in English, has brought attention to Albanian literature by way of several books of translation as well as critical works on politics, culture, history and individual authors. There is as yet no significant body of literary criticism which analyzes broad thematic trends and poetic memes in texts from a variety of periods and places. This essay seeks to serve as a foundation for this kind of synthetic scholarship. Through close readings of poems from the beginnings of Albanian literature to today on the inter-related themes of exile and nostalgia, this work emphasizes the evolution of Albanian attitudes about colonization and independence as they are viewed from at home and in the diaspora.
\end{abstract}

Keywords: : Albania, exile, poetics, diaspora

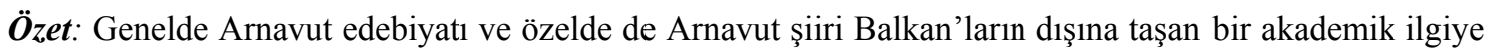
sahip olmuştur; ancak halen okuyucu ve eleştirmenlere bu edebiyatın sunacakları çoktur. İngilizce yazan Arnavutbilimcilerden Robert Elsie yapmış olduğu çeviriler ve politik, kültürel, tarihsel ve bireysel yazan bir çok yazar hakkındaki eleştirileriyle Arnavut edebiyatını çalı̧an bir kaç kişiden biridir. Ancak, bir çok tarihsel dönem ve coğrafi bölgeden gelen edebi metinlerin konularını ve şiirsel özelliklerini konu edinen çalışma halen çok azdır. Bu çalışma işte bu gereksinimi temellendirmeyi hedeflemektedir. Arnavut edebiyatının başlangıcından günümüze kadar yazılmış şiirlerin incelenmesiyle sürgün ve nostalji konularına odaklanan bu çalışma Arnavut edebiyatının kolonicilik ve bağımsızlığa yurt içi ve dışında yaşayan Arnavutlar tarafından bakışını ele almaktadır.

Anahtar Sözcükler: Arnavutluk, sürgün, şiir, diaspora

\section{Exile, Nostalgia and the Foundations of Secular Literature in Albanian (1731-1800): Nezim Frakulla and Nicolla Chetta}

"We have set off into exile, / May the Lord have mercy, / And protect us on our journey, / Farewell to Berat of roses!" (Elsie \& Mathie-Heck, 51). Thus the Albanian poet Nezim Frakulla (16801760 ), one of the first poets to write original lyric poetry in Albanian, begins his poem on one of its most common themes: exile and nostalgia. The conquest of the Illyrians (the ancient tribe who lived on the eastern edge of the Adriatic Sea and from whom modern-day Albanians trace their descent) by the Romans in $168 \mathrm{BCE}$ marked the last period of an independent Albanian state in the region until the beginning of the twentieth century when, in 1912, Albania declared its independence. Independence for the other majority-Albanian nation, Kosovo, was not achieved until 2008. During this long period, Albanians were ruled by successive foreign empires: the Romans, the Byzantines, the Ottomans, the Italians and the Serbs and, during much of

\footnotetext{
* Assist. Prof. Dr., Uppsala University, Department of Linguistics and Philology, Uppsala, Sweden. adam.goldwyn@lingfil.uu.se
} 
this period, they faced not only the common economic plights of imperialand colonial subjects such as poverty, unemployment and lack of education, but also systematic ones, such as the suppression of Albanian language, traditions and social structures. The Ottomans, for example, rightly or wrongly regarded Albanian-language education and books as subversive and saw fit to place a ban on all Albanian schools and publications, thus plunging the whole country into unremitting darkness and ignorance. Any Albanian-language schools which did manage to open were shut down immediately. Even into the twentieth century, the Ottoman authorities often went so far as to open people's handbags and correspondence, and search homes for anything written in Albanian... The prison in Vlorë was said to be full offenders having possessed writing in Albanian (Elsie, 1995, 281). Given both the continuity of foreign rule in Albania, the restrictions on free speech, the censorship of academics and the difficulty of translating those critical works that do exist from Albanian into English, it is no surprise that the voices of Albanians have not been widely heard outside Albania. Robert Elsie's translations and critical works are the foundational texts of Albanian studies in English and are essential in this regard, showing, as they do, the many universal aspects of the Albanian experience and Albanian literature while also emphasizing the uniqueness of Albania's individual poets.

A corollary effect of the lack of Albanian voices themselves is that this vacuum has often been filled by non-Albanians speaking on Albania's behalf - and not always either accurate or positive. Derek Hall (1999), in his survey of Western European attitudes towards Albanians from Julius Caesar to the 1990s, demonstrates that there is a "sense of the 'Other,' contrasted with developed, integrating, 'Christian' Europe, which has characterized the way Albania has been represented" (161). These representations have consisted of (1) "The Balkan people as heir to the ancient civilizations of the Classical world," a view which came to be seen in a pejorative way when "Western writers travelled to the cradles of Western civilization [and] were disappointed to find that the Balkan peoples were not upholding the 'classical' traits which they had hoped to encounter" (Hall, 1999, 165); (2) the Albanians as "marginal to "the 'Orient"' because of 400 years of Turkish occupation. Hall argues that this view is defined by a "view of the Balkans as being characterized by growing, yet dangerous permeability, situated on the decaying fringes of the Orient superimposed upon perceptions of an enforced backwardness which precluded access to the agrarian and industrial revolutions of Western and Central Europe" (166); and lastly (3) "As the home of folk cultures: the (noble?) savage" (Hall, 1999, 167). This last view attests to the "preoccupation with primitiveness [which] appeared frequently" in Western travel writing on Albania: "Savagery' is seen as one component of a more generally 'elemental' quality of human life, and certainly, this 'folk'/ 'savage' elements has tended to be the focus of images of Albania transmitted by Western media in their portrayal of post-communist events" (Hall, 1999, 167). The end result is that, unable to be heard in their own right, Albanians (like so many "subalterns" in the post-colonial model), were defined by their colonial occupiers rather than on their own terms. In this sense, Albanian lyric poetry on exile, so often nationalistic in theme, achieves an added nationalist purpose by creating an autochthonous (if exiled) Albanian national identity and discourse.

Even once Albania attained independence, moreover, conditions improved little. After the reign of the relatively liberalizing King Zog (1928-39) and the Italian occupation during World War II (1939-1945), the social, political and economic situation deteriorated further under the harsh Communist dictatorship of Enver Hoxha, which lasted from the end of World War II until five years after his death in 1985. Hoxha maintained power in large part through political oppression: censorship of speech and writing, physical intimidation, the imprisonment of political dissidents, assassination and other forms of totalitarian control. For the cultural and political context of Albanian literature under Hoxha, which consisted almost exclusively of socialist realism (not just in literature, but in painting and other forms as well), cf. Arshi Pipa's 
Contemporary Albanian Literature (1991). Pipa's analysis of the stagnation of Albanian literature under Hoxha is particularly resonant to the current discussion: unwilling to adopt the socialist realist demanded of artists after Hoxha's rise, Pipa served ten years in prison after a second show trial (the first had resulted in a two year sentence) which he describes in detail in Contemporary Albanian Literature: "I was in pajamas, having been abruptly taken from the prison section of the Durrës hospital. The session lasted about fifteen minutes. I refused to answer the framed-up questions about my 'counter revolutionary' activities. The second sentence added a zero to the first. Later an amnesty reduced the figure to ten years which I served in various prison and forced labor camp" (Pipa, 1991, 21). Pipa adds that "[i]t was during my in camera trial that I learned from Hakani that my brother, Muzafer Pipa, had 'paid for his sins with his life" for writing anti-fascist tracts and participating in the "failed Postriba insurrection (September 1946) led by Ballists and other nationalists. Accused of being part of their leadership, he was tortured and then shot in the Shkodër Security Section. He was at the time betrothed to Drita Kosturi, a former party member turned renegade. She was subsequently arrested and spent many years in jail" (Pipa, 1991, 21). After his release in 1956, Pipa escaped to the US, eventually settling as a professor at the University of Minnesota. Elsie (1991), for example, writing about the purge of intellectuals immediately after Hoxha consolidated power, says:

The Catholic writers of the north were of course among the first to be eliminated by the new regime: the poet Lazër Shantoja (1892-1945) was shot in the spring of 1945; the poet Bernardin Palaj (1897-1947) died in prison in Shkodër around 1947; Vinçenc Prennushi (1885-1949), poet, folklorist, and Archbishop of Durrës, was tortured to death in Durrës in February 1949; Ndoc Nkaj (1864-1951), often called the father of twentieth-century Albanian prose, was arrested in 1946 at the age of eighty-two on the absurd charge of planning to 'use violence to overthrow the government' and died in Shkodër prison five years later. Repression was not confined to Catholics, however. (257).

After listing the various writers who suffered death or exile under Hoxha, Elsie (1991) concludes, "No one will ever know how many gifted writers and artists were dispatched to do menial chores in dangerous branches of industry or banished to the provinces forever, to internment in some isolated mountain village with no hope of return" (258). Those independent non-state sanctioned poets of this period who were not purged, then, not only suffered exile in the traditional sense of being forced abroad, but also internal exile, wherein the victim is forced to stay in the country but lives, in a more real sense, apart from society in, for example, labor camps or detention. The exact definition of exile varies from scholar to scholar. John Glad, for example, distinguishes between the "expatriate... who regards his new address as his 'current primary' residence, but who returns home from time to time;" the "internal émigré," which he defines as "a writer [who] does not leave but might like to;" the " involuntary émigré,' who makes the decision to leave under coercion;" and the "true 'exile,' who is transported abroad against his will and is not permitted to return even for a visit" (Glad, 1990, ix).

Thomas Pavel (1996) offers a less expansive definition, arguing that only the last of Glad's categories is truly exile. Exile, he writes "[I]mplies the idea of forced displacement (as opposed to voluntary expatriation) that occurs for political or religious reasons rather than economic ones (as opposed both to slave trading and to voluntary migration)" (306).

For a further distinction based on etymology, cf. McLennen (2004), who distinguishes between the "exile... where the prefix 'ex' means 'out' and the root 'solum' refers to 'ground, land, or soil" and "expatriate, which is a term that also comes from the Latin 'ex' but is combined instead with 'patria' (fatherland of native land)" (18). McLennen further distinguishes 
these from "refugee, originating in the Latin 'refugiare' and meaning, 'to flee, run away, escape"" and "diaspora [, which] comes from the Greek 'diaspeirein,' 'to spread about"' (18).

For the purposes of this article, I put all of these distinctions under the broader heading of "exile": in a relatively prosperous country such as Germany during the inter-war period, the flight of Jews may be attributed to religious rather than economic reasons; even so, the religious persecution is what led to deteriorating economic conditions and, thus, the move abroad. In a country such as Albania, where widespread poverty, economic stagnation, political and religious oppression and lack of opportunity are intertwined, a move abroad for one reason can often hardly be distinguished from another. In all but the most clearly defined cases of political exile (which are also the fewest in number), the reasons for moving abroad fall somewhere in between these fixed ideas of "voluntary" and "involuntary" movement, between "exile," "émigré," "refugee" and "expatriate."

The crucial component of exile, then, is not to be found in the "coercive nature of the displacement" in the sense in which Pavel uses it (though this is often an important component), but rather in the distinction he makes between the exile and the immigrant: "Immigrants begin a new life and find a new home; exiles never break the psychological link with their point of origin" (McLennen, 2004, 306). It is this last component, this inability or unwillingness to let go of the hold that Albania has on the poetic imagination which determines the selection of authors in this article.

As a result of these conditions, the Albanian people have a long history of emigration and exile. Harry Papaganos and Peter Sanfey (2001) calculate that "[T]he number of Albanians living abroad has increased steadily throughout the decade and in 1998 it was estimated (by the Greek Ministry for Foreign Affairs and the Albanian Ministry of Labor) that more than 650,000 (about 20\% of the population) were living abroad, many of them temporarily" (492). By way of comparison, the authors note that in a 1992 study in which "[M] ore than 60\% of Albanians said that they were either 'definitely' or 'probably' emigrate, while, with the exception of Moldova, the next highest percentage in these categories is Georgia with 42.3\%. In most countries, more than $80 \%$ say they will probably or definitely not emigrate" (493). The numbers show the emigration from Eastern to Western Europe is by no means a uniquely Albanian phenomenon (just as the writing of exile literature is not); what it does show is the high rates, even by Eastern European standards, at which Albanians move abroad. As importantly, the authors conclude that "[T] hese results suggest that, to some extent at least, the people who intended to leave Albanian in 1992 were those whom the country could ill afford to lose, namely educated young men" (500). The educated young are also the class, perhaps not coincidentally, from which poets also come. It is perhaps prudent here to follow Paul Tiyambe Zeleza's (2005) acknowledgment that "The detour into the analytical gaze of the social sciences helps to demystify exile, to remind us that dislocation, expatriation from home is a prosaic condition experienced by millions of people rather than an exceptional reality only for those blessed with artistic souls. This is not to deny that writers and intellectuals experience exile in specific ways peculiar to their sensibilities and vocation, it is simply to disclaim the conceit that their experience is representative, universal, to guard against the fetishism of exile" (12).

These large numbers of Albanians were either involuntarily forced into exile for political reasons, or voluntarily in search of better political conditions such as basic freedoms and human rights or economic ones such as material wealth or a better education. In this, the collective Albanian experience as well as those of the individual Albanian poets discussed here, are no different from those of many other individuals and groups: "In recent centuries [exile] most often takes the form of individual mobility (as opposed to collective migration and diaspora), although in a more primitive historical environment it can involve an entire nation, for example, the Jewish exile to Babylon or the exile of the Crimean tartars" (Pavel, 1996, 306). The 
Albanian experience can be described as both an individual and national exile. Many individual Albanians went abroad, but Albanians as a nation also suffered mass deportations numerous times in their history. For a more detailed explanation of the suffering, deportation and mass murder of Albanians during the Balkan Wars (1912-13), cf. Freundlich (1998).

Nevertheless, like other displaced peoples, the idea of the homeland retained a powerful pull on their minds and imaginations. It is no surprise, then, to find that both exile and nostalgia appear as recurring paired themes in much of Albanian poetry. What poems on these subjects share is a deep ambivalence about the country left behind and the country in which one currently resides: an often unspoken gratitude for the opportunities the host country provides as well asresentment at the disorientation and social exclusion that often comes with being an immigrant as coupled with a sense of nostalgia for the traditions, culture and people of the native country.

Emigration of any kind is also often linked with the movement from undeveloped, primarily rural and agrarian societies to highly industrialized and dense cities, and this is particularly true of Albanian exiles who, under the Ottomans went to Istanbul, under the Communists went to Moscow and, in more recent times, to such Western capitals as London, Paris or New York. In his preface to Writers in Exile, Andrew Gurr (1981) argues that it is this very move from rural to urban which gives rise to literature of such creative force: "The broad proposition of this book is that the pressures of creative exile on those modern writers who were born in colonies and who took flight to the metropolis could be enormously constructive... The reason lies partly in the stronger sense of home which the exile has, and in the clearer sense of his own identity which his home gives him" (9). Gurr argues, moreover, that "[A]rt in the small, immobile, close-knit communities which sociologists call Gemeinschaft is confined and shaped by forces quite distinct of the Gesellschaft, the large, impersonal and individualistic societies which urban man has built for himself. In the small community art tends to be conservative, traditional, conformist. Artistic freedom rules only in the metropolis" (7). Many Albanian writers did indeed find their literary voice abroad (NezimFrakulla, for example), and many of them also exemplify the dichotomy between the rural home and the urban place of exile (for which, see Capriqi's $M y$ Room in London and My Room in Ulqin below). Perhaps as a result of this, the physical features of the land itself and the natural environment feature prominently in the works of Albanian writers in exile: the mountains, the forests, the farms and the small comforts of the familiar rural life which most Albanians knew stand in stark contrast to the wild unpredictability of life in foreign cities. The opening lines of "We have Set off into Exile," therefore, capture not only the ambivalence of the individual poet's own exile, but also the collective sentiment of Albanians for whom such exile was a major component of their national historical narrativeand identity. By giving Berat, theAlbanian city inwhich Frakulla resided, the epithet of "roses," he conjures its beauty, sweetness and richness. But even Berat of roses was incapable of meeting the author's intellectual needs: it was as a student in Istanbul where his creativity first flourished and where he had access to the broader tradition of poetry in the Muslim tradition. It was in Istanbul "where he wrote his first poetry in Turkish, Persian, and perhaps Arabic" (Elsie \& Mathie-Heck, 2008, 45). He returned to Berat in 1731 and only then, employing the knowledge and skill he first developed in exile, began to write poetry in Albanian and lay the foundations for a secular Albanian poetic tradition. This was not to be the end of Frakula's wanderings, however: " $A t$ some point after 1747, after having returned to Istanbul in search of work, he was sent to Khotin in Bessarabia (now in the [sic] Ukraine), probably into exile" (Elsie, 1995, 100). Returning eventually to Berat, "he seems to have been imprisoned. At any rate, he died in old age of cholera as a prisoner in Istanbul in 1760" (Elsie, 1995, 100). It was on a return journey in 1747 that Frakulla recounts his return to Albania, expressing again the same sentiment he felt about Albania when first he left: "Elbasan we entered with delight, / As sweet as sugar, oh 
Nezim!" "Në Elbasan hym me gzim / posisheqer o Nezim" (Elsie, 1995, 100). Sad to leave Berat for Istanbul, he is happy to return there via Elbasan. As Albanian Muslims would seek opportunity in Istanbul, the Albanian Christian community often looked west to Italy or to other European nations for intellectual and economic opportunity. Despite the difference in geography and religion, Frakulla'sambivalence can also be found in the sonnet "Of Honorable Lineage / Farie se ndeerme ne Kuntise u bii" by Nicola Chetta (1742-1803), an Albanian poet who was born and lived in the Albanian diaspora community in Sicily and who "had the honour of having composed the first Albanian sonnet" (Elsie, 1995, 146). As Chetta was the first to write a sonnet, the quintessential European verse form, so too was Frakulla the first to write a divan, a traditional eastern form. As such, the poets represent not only early examples of early Albanian poetry, but also the extent to which that poetry was a product of non-Albanian educational systems and artistic traditions.

Though born and raised in Sicily, Chetta nevertheless feels a direct connection to his national homeland, describing himself as "a scion of the Albanian soil" (Elsie \& Mathie-Heck, 2008, 61). And yet, despite his attachment to, and longing for, Albania, Chetta recognizes the permanence of his exile, likening himself to a "featherless bird in a nest" "Vlastar i t'arbrit dhee" (Elsie, 1995, 147; Elsie \& Mathie-Heck, 2008, 61). Nevertheless, in the second quatrain, Chetta acknowledges and even celebrates what life in the diaspora community has afforded him: "It clothed him," he writes, suggesting the material benefits of diaspora life, and "girded him with manners, with wisdom," [E veshi e engjeshi me zakon, me urtësii] (Elsie, 1995, 147) suggesting the cultivation of more abstract virtues (Elsie \& Mathie-Heck, 2008, 61). In the last line of the stanza, he writes that "now a priest, the church took him for her spouse," [E nani prift klisha kurorë e vee] (Elsie, 1995, 147), thereby not only providing employment and its subsequent material security, but spiritual and religious fulfillment as well (Elsie \& MathieHeck, 2008, 61). Implicit in this list of the benefits of diaspora life is the relative poverty of Albania itself and its inability to provide for Chetta, Frakulla and the generations before and after them sufficient intellectual, spiritual and material fulfillment to keep them at home. Despite the tangible and intangible benefits of life in the diaspora, loyalty to his nation remains foremost in Chetta's mind: "Like a silkworm he exhausted himself / And wove, embellished and wrote this treasure / To enrich Albania in every possible way" [Si krymp mundafshi gjith e svis vetëehi / E ktë vistaar tuar, kjëndisi e shkroi, / se të kjosëj gjithë Arbrin ndjeer përtei] (Elsie, 1995, 147; Elsie \& Mathie-Heck, 2008, 61). In both this poem and "We Have Set Off into Exile," the authors express their ambivalence about life outside of Albania: though they are not necessarily eager or able to return, they remain loyal to the idea of their national home and to use the advantages they have found abroad to improve the material and intellectual conditions there.

\section{Exile, Nostalgia and Nationalism in the Poetry of the Rilindja (1831-1912): Vasko Pasha and Andon Zako Cajupi}

The sense of Albania as a rich land given over to poverty by foreign oppression found new life as the Albanian independence movement, the Rilindja, gained steam in the nineteenth century. The Rilindja, from 1831 until Albanian independence in 1912, produced many of the greatest works of Albanian poetry. The poetry of the period was deeply engaged in this project of national revival and, as could be expected under circumstances where many of the educated class received their education abroad, exile and nostalgia feature prominently in their works. Though the project of national revival was largely articulated through poetry, the majority of Albanians were in fact illiterate in "Imagining the Homeland: Poetry, Songs, and the Discourses of Albanian Nationalism," Jane Sugarman (1999) argues that "[a]mong Albanian speakers, the support of villagers for the nationalist cause was secured in part when nationalist poems - the 
medium of the literate middle class - were transformed into men's narrative songs, the medium of a rural population on the verge of literacy" (420). Sugarman then analyzes the transformation of the works of three Albanian nationalist poets of the Rilindja, Thimi Mitko, Naim Frashëri and Sali Butka, focusing on the transformation of poetry into song.

It was from this class of educated Albanian exiles that Vasko Pasha (1825-1892), the author of "O Albania, Poor Albania, / O moj Shqypni, e mjera Shqypni" comes. Pasha, born in 1825, left Shkodra, in Northern Albania, in 1847. As a soldier and Ottoman diplomat as well as an Albanian nationalist, Pasha held positions in Italy and England and died in Beirut in 1892, while serving as governor general of Lebanon. Though Pasha accrued wealth and power under the Ottomans, and though he lived most of his life abroad, he, like Chetta and Frakulla before him, kept his eyes firmly fixed on Albania. As Elsie $(1995,260)$ writes, "Though a loyal servant of the Ottoman Empire, Vasko Pasha devoted his energies as a polyglot writer to the Albanian national movement" (For a more detailed list of Pasha's non-poetic contributions, cf. Elsie, 1995, 260 ff). "O Albania, Poor Albania", "the most influential and perhaps the most popular [poem] ever written in Albanian" (Elsie \& Mathie-Heck, 2008, 77), was written in Istanbul sometime between 1878 and 1880 (Elsie \& Mathie-Heck, 2008, 77); like so much literature written in exile, the poem captures the longing for the very home he himself left in search of better opportunity while lamenting the fallen state of the nation which has forced him to leave it. This poem contains possibly the most famous line in all of Albanian literature, "The religion of Albania is Albanianism / Feja e shqyptarit asht shqyptarija!", the quintessentially nationalist sentiment which seeks to transcend the religious, social and geo-political divisions which linger just beneath the surface of Albanian life, then as now.

The poem begins by asking about Albania's current wretched state: "O Albania, poor Albania, / Who has shoved your head in ashes?" (Elsie \& Mathie-Heck, 2008, 77) [O moj Shqypni, e mjera Shqypni, / Kush tëkaqit me kryen'hi?] (Elsie,1995, 263). Pasha then quickly shifts from the current poverty and oppression to a listing of the nation's former glory: "Once you were a fine, great lady, All the world's men called you mother. Once you had such wealth and goodness, I With fair maidens, strapping young lads, / Herds and land, rich fields and produce, / Flashing guns, Italian weapons, / Heroic fellows and pure women, / You reigned as their best companion" (Elsie \& Mathie-Heck, 2008, 77) [Ti ke pas ken njizoy e ran, / Burrat e dheut të thirshin nan. I Ke pas shum t'mira e shum begati, / Me varza t'bukra e me djelm t'ri. / Gja e vend shum, ara e bashtina, / Me arm të bardha e me pushk ltina, / Me burra trima e me gra t'dlira / Ti ndër gjith shoqet ke ken ma e mira] (Elsie, 1995, 263). The rhetorical power of Pasha's description of Albania's former glory heightens the pathos of its great fall in the present: "How fare you today, Albania? / Like an oak tree groundward falling! / Trampled now, the world walks o'er you, / No one has a kind word for you. / Like snowcapped peaks, like fields abloom / You were clothed, now you're in tatters, you've no name or reputation" (Elsie \& Mathie-Heck, 2008, 78) [Por sot, Shqypni, po m'thuej, si je? / Por sikur lisi rrxuem për dhe! / Shkon, botasipri, me kamb e shklet, / E nji fjal t'ambël kurrkush s'ia flet./ Si mal me bor, si fush me lule, Ke pas ken vershun sot je me crule] (Elsie, 1995, 263). Pasha's description of Albania's fall evokes the natural beauty of the land, "the snowcapped peaks and fields abloom" and the depletion of its material wealth, symbolized, as in Chetta's "Of Honorable Lineage" by clothes.

The poem concludes with a call to a return to national glory encompassing the entirety of the Albanian nation "From Bar," in the south of modern-day Montenegro, "to far Perveza," in the north-west of modern-day Greece: "Our forefathers left us this land," Pasha writes, connecting the trials of the present to those of the past, "Let none touch, for we'll all die! / Let us fall as did our forebearers / And not shame ourselves before God" (Elsie \& Mathie-Heck, 2008, 79).

Born a generation after Pasha, the Southern Albanian poet Andon Zako Cajupi (1866-1930) emigrated first to Alexandria, where his father had become wealthy as a tobacco merchant, at 
sixteen to pursue his education and then to Geneva before returning to Heliopolis and writing poetry on nationalist themes (Elsie \& Mathie-Heck, 2008, 86). In Egypt, Cajupi joined a relatively new but prosperous and diverse Albanian expatriate community: "The Albanian community in Egypt had begun to develop shortly after 1805, when Muhammad 'Ali, who was partially of Albanian descent, became Governor-General of Egypt. Because it included northerners (Gegs) and southerners (Tosks), Chrsitians and Muslims, and individuals of urban and rural background, it probably came closest of all expatriate communities to a microcosm of the Albanian-speaking population" (Sugarman, 1999, 422). For expatriate Albanian community's role in fostering Albanian national sentiment, cf. Sugarman, 1999, 422 ff. Cajupi's poem "Motherland" captures the poet's nostalgic attachment to the land that he left:

Motherland's the country / Where I first raised my head, / Where I loved my parents, / Where every stone knew me, / where I made my home, I Where I first knew God, / Where my ancestors lived, / And left their graves behind them, / Where I grew on bits of bread, / Where I learned to speak my language, / Where I have my friends and family, / Where I've laughed and where I've cried, / Where I dwell with mirth and hope ,/ Where I one day long to perish (Elsie \& Mathie-Heck, 2008, 88).

[Mëmëdhe quhetë toka / ku më ka rënurë koka, / ku më ka dashur mëm' e atë, / ku më njeh dhe gur' i thatë, / ku kam pasurë shtëpinë, / ku kam njohur perëndinë, / stërgjyshët ku kanë qenë / dhe varret që kanë vënë, / ku jam rritur me thërrime, / ku kam folur gjuhën time, / ku kam fis e ku kam farë, / ku kam qeshur ku kam qarë, / ku rroj me gaz e me shpresë, / ku kam dëshirë të vdesë] (Cajupi, 1902).

From the safety of exile, Cajupi expresses a romantic view of his country, sketching a series of memories infused with a deep nostalgia, concluding, even, with an (unfulfilled, as it would turn out) desire to return.

What the romantic portrait of Albania omits in "Motherland" are the poverty, lack of educational institutions and business opportunities which led him to pursue his education, business and literary ambitions abroad. These factors, however, are described in another of Cajupi's poems, "Servitude / Roberia". The romantic and nostalgic portrait of Albania painted in "Motherland / Memedheu" is shattered by the poet's acknowledgment of his nation's deep and pervasive problems. He refers, in the poem's opening line, to Albania again as his "motherland," but this time, the ambivalence of his attachment to the nation is apparent: "Dear Motherland of mine, / I love you as you are, / But if I saw you free, / I'd love you even more" (Elsie \& Mathie-Heck, 2008, 88) [E dashura mëmëdhe, / të dua dhe kshtu si je! / Po kur të të shoh të lirë / do të të dua më mirë] (Cajupi, 1902). This stanza, which both opens and closes the poem, expresses the poet's ambivalence about his homeland. He loves it, as is evident from the opening line of the poem and his evocation of it as his "Motherland," and yet, he does not want to live there. As with his predecessors, Cajupi's poem focuses on the natural features of the country, writing in the second stanza: "Weep, O forests, plains, and stones, / Weep, O mountains under snows, / Poor Albania is abandoned, / never will she see the light" (Elsie \& Mathie-Heck, 2008, 88) [Qani pyje, fusha, gurë, / qani male me deborë! /Shqipëria mbet e gjorë / dhe nukë sheh dritë kurrë] (Cajupi, 1902). In "Motherland," Cajupi fondly recalls how "every stone knew me;" in "Servitude," he exhorts those stones to cry over the present miserable state of the country, while the "mountains under snows" become, like the "snowcapped peaks" in " $O$ Albania, Poor Albania," another symbol of the nation's fallen state. Mountains have a particular symbolic power in Albanian literature, as expressed in Elsie's description of Naim Frashëri's 
poem "Mountains of Albania / O malet'e Shqipërisë": "The pride of people fighting for their land and the love of Albania which pervade this verse are succinctly expressed in the opening lines which every Albanian schoolchild knows, or is supposed o know, by heart: 'O malet'e Shqipërisë e ju o lisa t'egjatë! / Fushat e gjera me lule, q'ukamndërdi t'enatë! / ...Zmërnëti ma gatove plot me dëshirë dhe me zjar...Oh mountains of Albanian and you, oh lofty trees! / Broad blossoming plains, you are in my thoughts day and night / ... Oh blessed place! How you nourish and delight me!" $(1995,232)$ The emotional connection to the physical characteristics of the land, and the mountains above all, as well as their nourishing power, are component elements of Frashëri's celebration of the joys of rural life in Albania.

The third stanza begins on an equally pessimistic note: "Darkness and misfortune on us, / Thunder, all around us, / Do we live with hearts a-frozen, / Dwell in fear, deprived of joy, / None in song do raise their voices, / And the nightingales are grieving:" (Elsie \& Mathie-Heck, 2008, 89) [Një gazep, një errësirë, / vetëtit edhe gjëmon! / Rrojmë me zemër të ngrirë, / nga frika kërkush s'gëzon! / Njërzit kurrë s'këndojnë / dhe bilbiletë vajtojnë!] (Cajupi, 1902). The depiction of Albania in "Servitude" is at odds with that in "Motherland." The poet in "Motherland" offers no reason for moving abroad: the Albania he describes is a romantic place of fulfillment, joy and the unmitigated pleasures of youth. And yet, the depiction of the country in "Servitude" offers no such space for fond recollections. In this poem, Albania is an oppressive place from which people choose exile rather than suffer the inevitable hardships and destitution of life under occupation.

Cajupi captures this ambivalence in the fourth stanza: "What disaster, desolation! / In their nests the birds take shelter, / Yet the people flee their own soil, / For a savage law does rule it, / Yes, Albania, we yearn for you, / Refugees in a foreign state" (Elsie \& Mathie-Heck, 2008, 89) [Qiameti, shkretëtira! / Zogu vetë zë folenë, / njeriu le memëdhenë, / se mbretëron egërsira! / Për Shqipëri dëshërojmë / se në vend të huaj rrojmë] (Cajupi, 1902). Even as those still in Albania flee from political and other forms of oppression and search for a new life abroad, they still long for the homeland from which they depart. As befits a patriotic poem written in the period before independence, the penultimate stanza, like "O Albania, Poor Albania," issues a call to arms to revolution: "O Albanians, swear an oath that / You will now fight for your homeland" (Elsie \& Mathie-Heck, 2008, 89).

\section{Exile and Nostalgia under the Italian Occupation and Communism (1939-85): Sejfallu Malëshova and Mitrush Kuteli}

Dying in 1930, Cajupi lived long enough to see the dream of Albanian independence realized, but not long enough to see it brought low again, first by the Italian occupation and then by Hoxha's Communist dictatorship. A generation younger than Cajupi, Sejfullah Malëshova (1901-1971) experienced both of these periods. Malëshova published under the pseudonym Lame Kodra. Personal secretary to Fan Noli, he was exiled to Moscow with the fall of Noli's government. Upon his return to Albania, Malëshova became a high-ranking member of the Communist government under Hoxha, even serving as Minister of Culture. His poems continued to circulate even before ideological differences with Hoxha led to his imprisonment in a labor camp for three years after World War II, then to "internal exile as a humble stock clerk in Fier, where for years no member of the town dared speak to him... Whenever anyone approached, he would pinch his lips with his fingers, signifying the vow of eternal silence that ensured his survival" (Elsie, 1995, 126). He died after 25 such years of silence. His 1945 collection of poems, titled simply Verse, contains conflicting views of the homeland as viewed through the twin prisms of revolution and exile.

Though the expatriate critic Arshi Pipa (1970) derided him at the height of Hoxha's dictatorship as "a good writer but not an authentic poet" as part of his larger critique of 
Albanian poetry. Malëshova's poems nevertheless capture the ambivalence of the longing for a spiritual return to the home to which he has no physical connection: "I've no farm or estates or manors, / I've no shops or lofty buildings, / Yet I love my land, Albania" he writes in "How I love Albania / Si e dua Shqipërinë" (Elsie \& Mathie-Heck, 2008, 126) [S'kam çiflik e s'kam pallate, / S'kam dyqan me katër kate, / Po e dua Shqipërinë] (Malëshova, 1945, 18). Pipa contrasts Malëshova, "The founding father of Albanian Communist Literature" with Martin Camaj, whose poems "show him to be a talented poet with a definite poetic theme, that of his native North Albanian highland" (1970, 53). Pipa praises Camaj for writing "[n]ot with the exile's nostalgia, but a virile sense of belonging sharpened by exile... Camaj strikes a felicitous middle chord which is neither praise nor compassion, but a deeper, graver, almost physical sense of identiy with his own land" $(1970,53)$. In this, Pipa sees Camaj's poetic connection to the land as perhaps a more pure (in the sense of not being "versified propaganda") poetic expression than Malëshova's. Different, then, as these poets may be, they are bound by a shared ideological and poetic connection to the land from which they were driven and long to return. Malëshova articulates the exile's plight: though he has no claim on the land itself, no physical ownership or material property, he loves it nevertheless as the abstraction it must be to him. Forced abroad, Albania grows as a symbol for all the things he left behind.

Like many of his fellow poets in exile, Malëshova's poems often focus on the natural bounty of the land itself: "Yes, I love my land, Albania, / For the clover in its meadows, / For a quick and agile maiden, / For its spring of water gurgling / From the cliffs and flowing swiftly / Through the leafy oak tree forests, / Tumbling down to form a river, / Yes, I love my land, Albania" (Elsie \& Mathie-Heck, 2008, 127) [Unë e dua Shqipërinë, / Për tërfilin mi lëndinë, / Për një vaze gjeraqine, / Dhe për ujët qe buron / Nga një shkem e gurgullon / Neper lista gjetheshume, / Edhe zbret përposh ne lume./ Unë e dua Shqipërinë] (Malëshova, 1945, 18). Given the deep poverty of the people and their oppressive governments, Malëshova cannot celebrate the accomplishments of the society. He therefore turns to the land itself, evoking a more natural and innocent state of the country without the depravations of its ruling class. Accordingly, Cajupi's "My Village" contains a similarly idealized view of rustic Albanian life: "The mountains rich in stone, / The meadows full of grass, / the fields replete with wheat, beyond them is a river. I Across from it the village / With church and rows of gravestones / And standing all around it / Are humble, tiny houses" (Elsie \& Mathie-Heck, 2008, 87). "Maletë me gurë, / Fushat me bar shumë, / Arate me grurë, / Metutjenjëlumë. / Fshatipërkarshi / Mekish'e me varre, / Rrotullcashtëpi / Tëvogëla fare" (Elsie, 1995, 349). Note again the invocation of mountains and fields, as in Frashëri's "Mountains of Albania" and Pasha's "Oh Albania, Poor Albania" Elsie comments that Cajupi's work is not purely romantic; the poem, he writes, "[F]ocuses for instance on the inequalities of the patriarchal society" (Elsie, 1995, 349).

Similarly, Malëshova's work celebrates the unity of the Albanian nation by referring to its cities. He evokes the humble buildings of the private citizen rather than celebrating the public symbols of the government. In the first stanza, for example, he loves Albania "[f] or a barn in Trebeshina, /...For a hut above Selishta, For two fields plowed in Zallishta;" [Për kasollen mbi Selishte, / Për dy ara ne Zallishte] (Malëshova, 1945, 18). Later, he loves Albania "from Skopje to Janina," two cities that, despite their large Albanian populations, had not been incorporated into the modern Albanian state and whose people, he writes, "[i]n misfortune / Suffer, live their lives in serfdom" (Elsie \& Mathie-Heck, 2008, 127) [Qe nga Shkupi e Janine, /Ku një popull derëzi / Heq e vuan robëri] (Malëshova, 1945, 18). The poet's obvious pride in the natural beauty of the land and his fondness for its cities, however, is tempered by the reality of the circumstances. After a long list of the diversity of Albania's virtues, Malëshova concludes by offering a view of a different Albania at odds with the Albania of the preceding lines, an Albania of "misfortune," "suffer[ing] and "serfdom." 
Only alluded to at the end of "How I Love Albania," Malëshova expands on the theme of release from oppression in "Rebel Poet / Poeti Rebel": "Listen to me, men and women, / Everywhere, / There's a warrant out to snare me / from Tirana. / Over hill and over dale and / in the fields, / Their patrols are right behind me / step by step" (Elsie \& Mathie-Heck, 2008, 128) [Pa dëgjoni, gra e burra, / Anmbanë / Doli urdhëri për mua / Në Tiranë. / Nëpër male, nëpër fusha / Në luadhe /Po më ndjekin këmba-këmbës / Me koshadhe] (Malëshova, 1945, 13).

Malëshova contrasts the purity of the natural environment, with its seemingly unspoiled hills and dales and fields, with the oppression which sullies that land. Malëshova, moreover, takes consolation in the goodness of ordinary people in opposition to the oppression of the government: "I fear not their hunting dogs / and all their guns, / I am off and make my journey / path by path, I am off and will find shelter / house by house, / Everywhere in this, my country, I have my lair" (Elsie \& Mathie-Heck, 2008, 128) [Po s'kam frikë nga zagari / Me dyfek / Kudo shkoj e hidhem unë / Shtek më shtek. / Kudo vete e futem unë / Prak më prak / Shqipërinë anembanë / Kam jatak] (Malëshova, 1945, 13). The government, Malëshova suggests, and not the people of Albania and not the land itself, is what is evil and oppressive.

The goodness of ordinary people and the oppressive nature of the government is elaborated in the poem's ensuing lines: "Who's behind me, searching for my / every trace? / Stop a while and listen to me, / soldier boy, / Are you not a peasant's son, a / village lad? / Bide a bit and listen to me, / brother mine, / Hold you pace and save your bullet / for those men, / For the ones who rob, oppress our / piteous home" (Elsie \& Mathie-Heck, 2008, 129) [Kush ngre pushkën kundër meje / Kështu vallë? / Kush pas gjurmëve të mia / Vjen vërdallë? / Qëndro pakë, dëgjo mua, / Or ushtar / Nuk je vallë bir fshatari, / Ti, fshatar? / Qëndro pak, dëgjo mua, / Or vëlla / Mbaje dorën, kurse plumbin / Për ata / Për ata që rrjepin, shtypin] (Malëshova, 1945, 13). It is fitting for a revolutionary poet such as Malëshova to attribute the source of Albania's rot not to the land or the people - even the soldier chasing him is his "brother" and a "peasant's son" but rather to the political elite who issue such orders.

"Rebel Poet" concludes with a call to arms to overthrow the government. This revolutionary stance relies again on the innate goodness of the Albanian people, victims of the very oppression in which they themselves are enforcers. Emphasizing national unity, Malëshova calls on the cities by name to join him:

Let our country's people gather everywhere / Let the tyrant tremble, quiver in his hall. / To your feet arise, O Korça, matriarch, / with Devoll and with Kolonja, with Opar... / To the vanguard like Gjoleka, Kurvelesh, / Beat upon them Cameria... / Rise up, people, like a lion, cast the yoke, I In Berat and in Tirana, Elbasan, / And you, Mat, Luma, and Dibra... / Come along, arise Kosova, join the dance, / With Krasniqi, Bajram Curri and Tetova (Elsie \& Mathie-Heck, 2008, 129).

[Anembanë Shqipëria / Le të mblidhet / Në pallate tirania / Le të dridhet. / Ngrehu Korçë, Korç' o lule, / Korça-Zonjë, / Me Devoll e me Opar, / Me Kolonjë. ... / Shko në ballë si Gjoleka, / Kurvelesh, / Hidhu ti,moj Çamëri... / Ngrehu, popull, shkunde zgjedhën / Si luan, / Në Berat e në Tiranë, e / N'Elbasan. / Dhe ti Mat e Lumë e Dibër... / Hajde, hajde, tunde vallenë / Moj Kosovë, / Me Krasniqn'e Bajram Currit, / Me Tetovë] (Malëshova, 1945, 13).

Invoking cities large and small alike by name, Malëshova suggests his nostalgia for a freer Albania and his faith in the freedom-loving nature of Albanian people. The very need for such an exhortation as this - not to mention the ensuing events of the poet's own life - however, 
belies the poet's own faith in his countrymen. A similar rhetorical strategy is employed by the Albanian writer Xhevahir Spahiu. In "Kosova," the poet writes "The peasants I my part of the country [Albania] asked me about Kosova" (Elsie \& Mathie-Heck,2008, 214). In 1994, Albania was both independent and newly democratic. Kosova, however, suffered under the resurgent Serbian nationalism of Slobodan Milosevic, which would lead to the brutal Serbian invasion and NATO retaliation in 1999. Spahiu's response to this peasant's question follows Malëshova's description of Albania; he lists the natural features of the land: "River Drin, River Osum, / Mount Sharr, Mount Tomorr, / Here and there the same words are spoken. / One difference is certain: / The shackles" (Elsie \& Mathie-Heck,2008, 214). The Drin runs through Kosovo, the Osum through Albania; Mount Sharr is in Kosovo, Tomorr in Albania. Arguing implicitly for a united Albania including both Albania and Kosovo, Spahiu contrasts the glories of the natural environment with the oppressive political situation ("the shackles").

A similar fate befell Malëshova's contemporary Mitrush Kuteli (1907-1967). Born in Pogradec, Kuteli moved to Romania, returning in 1942. In 1947, he was sent to a work camp "where inmates were put to work draining the infamous mosquito-infested swamp of Maliq" (Elsie \&Mathie-Heck, 2008, 131). Drawing on this experience, Kuteli composed "The Muddy Albanian Soil / Balta Shqiptare," in which he expresses both his love for the land but also acknowledges the hardships that he has endured. "I love you, muddy Albania soil," he writes, "I love you... / Up to my knees / I am into you, / For I was born / Here, / Like my father, / like my grandfather" (Elsie \& Mathie-Heck, 2008, 131). "Tëdua, Baltë shqiptare! / Tëdua: ... / Si gjermbigju / jam brenda teje; / se ler Se lerëkam / ketu: / si Baba / e Gjyshi” (Kuteli, 1944, 55). Even while working in the labor camp, the result of the oppressive government, Kuteli can't shake the nostalgia to the past, represented by his father and grandfather, and his love for the land itself. In the ensuing stanza, Kuteli finds himself deeper in the mud, a symbolic representation of the increasing depth of his oppression, now "Up to [his] waist" and deeper; the Albanian mud "bind[s him] / And captivate[s him] ... / For my mother / And my father / And my ancestors / All perished / Here" (Elsie \& Mathie-Heck,2008, 132) [Si gjer mi bel ... / se timë lidh / e mëmban: .../ Se vdekurka, / këtu, / dhe Nëna, / dhe Baba, / e Gjysh - stërgjyshi!] (Kuteli, 1944, 55). The optimistic note of the poem's second stanza, noting the birth of his ancestors is contrasted with the pessimistic note in the later stanza, that those same ancestors also died there. Kuteli is able to love the soil even as he is imprisoned and compelled to do forced labor upon it. He loves it "sweet as honey" as his home and the place of his ancestors' birth, but "bitter as wormwood" as the place in which he is oppressed and the place in which his ancestors and, by extension, he himself, must die (Elsie \& Mathie-Heck, 2008, 132); [timjaltë e ëmbël; Pelin e hidhur] (Kuteli, 1944, 55).

What these poems all share is a vivid sense of a glorious land abundant in all the good things of life, a land rich in potential and full of strong and noble people. Yet, these are all poems by poets who, for a variety of reasons, left that land even despite its goodness and their own emotional attachment to it. The fault, therefore, must lie neither in the land nor its people. More often than not, these authors attribute the blame on an oppressive political leadership. Thus, the poems of Pasha, Cajupi and Malëshova all call for revolution to replace the existing government with a new one which will, they hope, allow the potential of the land and its people to be realized.

\section{Exile and Nostalgia after Communism (1980- the present): Basri Capriqi and Sabri Hamiti}

Perhaps the most potent expression of the competing claims of exile and nostalgia are expressed in Basri Capriqi's (1960- ) poems "My Room in London" and "My Room in Ulqin". In these poems, the poet employs an inventive marriage of form and subject matter to convey the 
immediate experience of both his life abroad and at home.

"My Room in London/ Dhoma ime në Londër," an unpunctuated single-sentence poem describes the literal and metaphorical suffocation of life in exile:

The traditional English-style window and the mirrors around it increase the illusion of space you watch me from the street and from the surrounding apartments I cannot lock anything with the key that binds me to you the Thames takes it all and casts it down by the two flanks of my naked body surrounded by mirrors that increase the illusion of infinite space in my bedroom I cannot lockthis cubic world with the key that separates me from you the Thames takes my little belongings and I cannot find them in the shadows suffocating the traditional English-style window and the confusing key in the open door fracture the light into a multitude of views of my limbs hanging in the mirrors that turn to ruins my world hidden from public view and the masses (Elsie \& MathieHeck, 2008, 243).

[dritarja tradicionale angleze dhe pasqyrat rreth që më rrisin iluzionin për hapës irën Ti më sheh nga rruga nga apartmentet përreth gjë s'mund të mbyll me çelësin që më lidh me tytëgjitha i merr Temza $i$ hedh në të dy anët e trupit tim të lakuriq të rrethuar me pasqyrat që më rrisin zbrazëtinë e hapësirës pa fund në dhomen time të gjumit s'embyll dot këtë botë kubike me çelësin që më ndan me ty m'i merr Temza gjërat e vogla e s'igjej dot udër hija që më marrin frymën tek parakalojnë në pasqyrat që më zgjasin dhomën time të gjumit dritarja tradicionale angleze dhe çelesi i ngatërruar në derën e mbetar hapur thehet drita me pamjet e shumëfishuara të gjymtyrëve të mi në pasqyrat e montuara që rrenojne botën time të fshehur nga sheshi e nga turma]

Capriqi draws attention in the poem's opening to the Englishness of the window, an implicit acknowledgement of that window's foreignness to him. The window and the mirrors surrounding it "increase the illusion of space," he writes. Significantly, however, Capriqi notes that it is only the "illusion of space," not an actual increase in space. The window, which looks out on the world is mitigated by the mirrors, which reflect back in upon themselves. Nor, for that matter, do these windows give him a sense of freedom; rather, they trap him in the gaze of the people outside: "you watch me from the street."

As the other poets of exile note the natural geographical features of their home, so too does Capriqi. But, like the rest of London, the Thames "takes it all and casts it down." As the river itself flows endlessly away from the poet, so too does the city it represents take everything from him. Indeed, the poem is structured like a river: a restless, ceaseless flow of words away and, if read out loud, a ceaseless breathing out.

The river "casts it down by the two flanks of my naked body surrounded by mirrors that increase the illusion of infinite space." The poem's structure reflects the image of mirrors, which, again, only "increase the illusion of space" and not the actual space itself. The repetition (with slight modification) of the poem's opening figure suggests the increase in space as 
illusory, not as something real. The repetition of the "Thames" increases this effect, though now the river "takes my little belongings and i cannot find them in the shadows suffocating me." Indeed, a reader reciting this poem out loud with appropriate regard for the lack of punctuation finds himself running out of breath almost precisely at the point where Capriqi invokes his own suffocation. The river, with its unidirectional flow, takes all things away from the poet (his nakedness, for example, contrasts with Chetta's exile, which clothed him), including his breath. The lack of space in the poet's room in London is as metaphorically suffocating as the literal experience of reading the poem.

The poet then returns to the original figure of the "the mirrors that extend the size of my bedroom the traditional English-style window and the confusing key." The mirroring effect on the visual composition of the poem is made literal, in a way that the space of the bedroom is not, by the mirrors in the poem while the windows which brought the illusion of space in the poem's opening now do not even hold out the possibility of such expansion. The poet's room turns in on itself, small, suffocating and unable to engage in the world beyond, a "world hidden from public view and the masses." Abroad, the poet is unable to get beyond himself and participate in the society at large.

"My Room in Ulqin / Dhoma ime në Ulqin" on the other hand, presents the author in a much different state of mind. "Even when I am not there" he begins, "My mother opens the shutters to the sea" (Elsie \& Mathie-Heck, 2008, 243). In the cramped, lonely and suffocating mirror-world which is his life abroad, the poet imagines a better life at home. Unlike the collective and invasive gazes of the anonymous masses in "My Room in London," the sole person in "My Room in Ulqin" is the familiar and reassuring presence of his mother. Unlike the windows and mirrors in London, the opening of the shutters in Ulqin does not give the illusion of increased space, but actually increases it.

As importantly, the water outside of his room is no longer the Thames, which takes all things from him, but rather the sea. The invocation of the tidal sea, with its rhythmic rise and fall stands in contrast to the Thames. Moreover, the full stop and the ensuing line break which end the stanza allow the reader to breathe in and pause, a physical movement which brings life and a sense of space to the poem and marks another contrast to the suffocating experience of life in London. In the final stanza, the open windows "bring in the fresh salt air" (Elsie \& MathieHeck, 2008, 243).

With the opening of the windows, "The moon floods in, outlined in a glass, / Filling the room with my figure" (Elsie \& Mathie-Heck, 2008, 243). Rather than the crack in the open door in London which "fracture [s] the light into a multitude of views of my limbs hanging from the mirrors," the open windows in Ulqin bring in not only the light of the moon, but the unified vision of the poet's own absent body. Thus, in form and style, in diction and syntax, the poet contrasts the experience of living abroad with his nostalgic image of his home. In London, there is the Thames, suffocation, anonymity and claustrophobic reflections of a fragmented self. In Ulqin, there is the Adriatic, expansive space and fresh air, an attentive mother and a fully realized self-made visible by a single source of light.

Given the deep despair he feels about life abroad, neither "My Room in London" nor "My Room in Ulqin" addresses the reasons behind the poet's decision to go abroad. However, his poem "Girl from the East, Prostitute in Rome / Vasha nga Lindja, prostitute ne Rome" suggests that it is nothing more than economic necessity: "They pay good money here / Full stop" (Elsie \& Mathie-Heck, 2008, 244) [Këtu paguajnë mirë] (Capriqi, 1996, 37). The poem's title evokes the long history of Albanian expatriation, oppression and economic desperation - it was to Rome, after all, that the Illyrians lost their independence, forcing them to make money however they could - while the poem's structure - modeled on the language of the telegram - shows the female narrator's longing for home and the difficulty of maintaining that connection. 
While acknowledging the increased economic opportunity available abroad, Capriqi also highlights the exploitation of exiles in their host country: "In Prague the minister of food production arraigned me / In the name of the people / Full stop / I was a member of the Party" (Elsie \& Mathie-Heck, 2008, 244) [[N]ё Pragë më kapte misteri i industrisë ushqimore / në emër të popullit dhe pikë / isha anëtare e partisë] (Capriqi, 1996, 37). The "minister of food production" represents the host country's control over even such basic human needs as food: the Albanians, and exiles in general, are "arraigned," a word which, with its sexual innuendo, suggests that both the governments and ordinary people have no problem taking advantage of the exiles among them while its literal meaning points to the legal, societal and culturalobstacles that these immigrants faced. Theensuingstanza repeats the economic incentive for emigration: "They pay good money here/ And the minister of heavy industry / And the people / Full stop" (Elsie \& Mathie-Heck, 2008, 244). [[K]ëtu paguajnë mirë dhe pikë / edhe ministri i industrisë së rëndë/ edhe populli / dhe pike] (Capriqi, 1996, 37). As the "minister of food production" in the previous stanza suggested, through its use of sexual imagery, the degradation of Albanians in search of food, so too the "minister of heavy industry" shows that a similar degradation occurs in their search even for menial labor. This time, however, the prostitute is "not permitted to be a member of their Party" (Elsie \& Mathie-Heck, 2008, 244) [[D]he s'duhet të jem patjetër anëtare e partisë / së tyre] (Capriqi, 1996, 37). The prostitute is good enough for them to party with in the sense of sexual exploitation and the other ways in which immigrants improve the lives of their hosts, but not good enough to join the party in the sense of full membership in the political and social institutions which would allow them to interact with their hosts as equals. A more damning picture of the plight of exiles could hardly be imagined: forced to sell their bodies for money abroad, they are welcomed in those ways which are satisfy the host country's needs, but not in those ways which allow them full membership into that society.

Capriqi's contemporary Sabri Hamiti (1950-) employs a similar poetic form to illustrate a different perspective of the immigrant experience. In "The Telegram," Hamiti offers a complementary perspective to the voices of centuries of poets in exile. "You're off in Europe and we don't know where you are stop" the poem begins, placing the narrator in the Albanian national home even as he laments the departure of the telegram's recipient (Elsie \& Mathie-Heck, 2008, 222). "Stop" each line ends, both mimicking the style of the telegrams but also, when read as an imperative, beseeching the telegram's recipient to stop, that is, to return home (though this meaning is more forceful in the English translation). "You turned twenty-eight today stop" the poem continues, "And Mirani turned eight stop" (Elsie \& Mathie-Heck, 2008, 222). The poet highlights the passage of time and all the good things of life that the addressee, abroad, is missing, including his loved ones and the inconsequential milestones which give meaning to domestic life: "He's learned the whole alphabet stop / Last night he did all his homework stop / Penning it carefully in his notebook stop / Father bought some groceries stop" (Elsie \& MathieHeck, 2008, 222).

This list of the mundane but meaningful acts of life, however, takes a dark turn: "He's coughing again stop" (Elsie \& Mathie-Heck, 2008, 222). The addressee misses not only lifeaffirming things, such as birthdays and educational milestones, but also illness. This first indication of the sorrows of life that the addressee is missing, however, is but a first step in the poem's increasingly dark turn: "Mother died three days ago stop / We buried her under the blooming hawthorn tree stop / We did not call you, did not know how stop / You're off in Europe and we don't know where you are stop" (Elsie \& Mathie-Heck, 2008, 222). The repetition of the poem's opening line has a far more sinister ring to it here, after the admission of the death of the poet's mother. The death of the mother three days ago reveals the true reason for the sending of the telegram, and the happy events such as the birthdays seem now hollow, all the more so, even, in light of the poem's later revelation. 
The poem originally seemed to indicate the telegram was simply a birthday wish which also would recount the daily lives of the people at home; it is only through a slow revealing that the real reason the telegram was sent was to let the addressee know of the death of his mother. The mother's death three days ago casts a gloom over the addressee's birthday today: "We did not eat cake for your birthday without you stop / The candles are burning and going out stop / Comeback alive for we are still waiting stop / stop stop stop" (Elsie \& Mathie-Heck, 2008, 222). Unlike the previous poems discussed here, this poem does not show us the inner state of the exile himself; rather, it shows the state of those left behind. The picture it presents is not a happy one: fear, uncertainty, sorrow and tragedy seem all that much greater in light of the banality of the positive aspects of life. The poem's closing lines demonstrate that life is often as bad for those left behind as it is for those who go abroad: in times of deep distress and trial, those at home do not even know where their loved ones are or even if they are still alive.

The final "stop stop stop" suggests not only the mimetic quality of the poem written in the language of the telegram, but also represents the poet begging for an end, not just to their sorrows in light of their dead mother, not just to their fear and uncertainty about the absence of the telegram's addressee, but more broadly, an economic, political and social climate which forces its educated young people to go abroad and which irrevocably shatters families, separating mothers from their sons, sometimes forever. The poem, then, wishes for an end to the circumstances of life which drive Albanians from their home, and holds forth the hope of a time in which no Albanian would ever again have reason to bid "[f]arewell to Berat of roses".

\section{Author's Note:}

The author wishes to convey his great appreciation to Rineta Hoxha for the hours she spent in the National Library tracking down books and for her insight on a variety of Albanian and Kosovar historical, cultural and aesthetic issues. All mistakes remain my own.

\section{Bio:}

Adam Goldwyn received his $\mathrm{PhD}$. in Comparative Literature from the Graduate Center of the City University of New York with a specialty in the literature, history and culture of the ancient and medieval Mediterranean. He was formerly Assistant Professor of English at The University of New York in Tirana (Tirana, Albania) and lecturer in English at the American University in Kosovo (Prishtina, Kosovo). He is currently a post-doctoral research fellow in The Department of Linguistics and Philology at Uppsala University (Uppsala, Sweden). 


\section{REFERENCES}

Cajupi, A. Z. (1902). Baba-Tomorri. Cairo.

Capriqi, B. (1996). Frutat Bizare. Prishtinë: Rilindja.

Elsie, R. (1991). Evolution and Revolution in Modern Albanian Literature. World Literature Today, 65(2), 256-263.

Elsie, R. (1995). History of Albanian Literature. New York, NY: Columbia UP.

Elsie, R. \& Mathie-Heck, J. (2008). Lightning from the Depths: An Anthology of Albanian Poetry. Evanston, IL: Northwestern UP. Freundlich, L. (1998). Albanian's Golgotha: Indictments of the Exterminators of the Albanian People. Trans. by S. Juka. Riverdale, NY: Juka Pub. Co.

Glad, J. (1990). Literature in Exile. Durham, NC: Duke UP.

Gurr, A. (1981). Writers in Exile. Sussex: The Harvester Press.

Hall, D. (1999). Representations of Place: Albania. The Geographical Journal, 165(2), 161-172.

Hamiti, S. (1983). Trunguilir. Prishtina: Rilindja.

Hart, L. K. (1999). Culture, Civilization, and Demarcation at the Northwest Borders of Greece. American Ethnologist, 26(1), 196-220.

Kuteli, M. (1944). Sulm e Lotë. Tirana: Nikaj.

Malëshova, S. (1945). Vjersha. Tirana.

McLennen, S. (2004). The Dialectics of Exile: Nation, Time, Language and Space in Hispanic Literatures. West Lafeyette, IN: Purdue UP.

Papapanagos, H. \& Sanfey, P. (2001). Intention to Emigrate and in Transition Countries: The Case of Albania. Journal of Population Economics, 14(3), 491-504.

Pasha, V. (1989). Vepra. Prishtinë: Rilindja.

Pavel, T. (1996). Exile as Romance and Tragedy. Poetics Today, 17(3), 305-315.

Pipa, A. (1991). Contemporary Albanian Literature. New York: Columbia UP.

Pipa, A. (1970). Modern and Contemporary Albanian Poetry. Books Abroad, 4.1, 51-54.

Spahiu, X. (1994). Ferrparajsa. Elbasan: Onufri.

Sugarman, J. (1999). Imagining the Homeland: Poetry, Songs, and the Discourses of Albanian Nationalism. Ethnomusicology, 43(3), 419-458.

Zeleza, P. T. (2005). The Politics and Poetics of Exile: Edward Said in Africa. Research in African Literatures, $36(3), 1-22$. 